\title{
A SigProfiler
}

\section{S1}

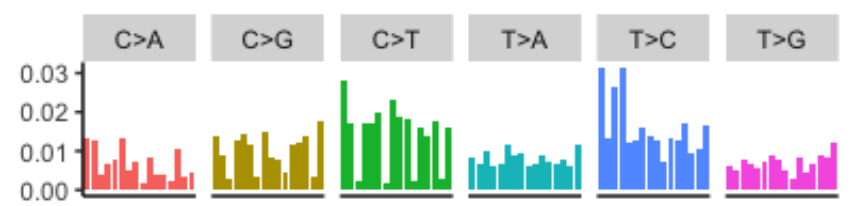

S3

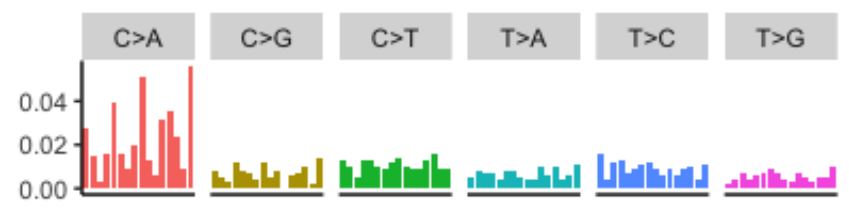

S2

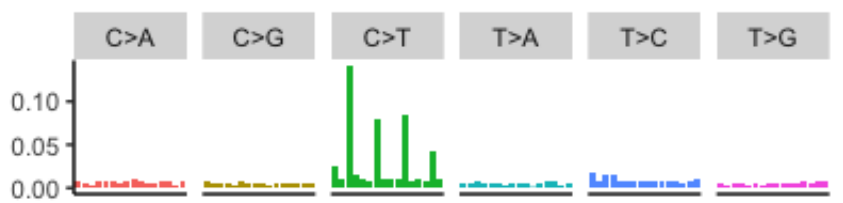

B SignatureAnalyzer

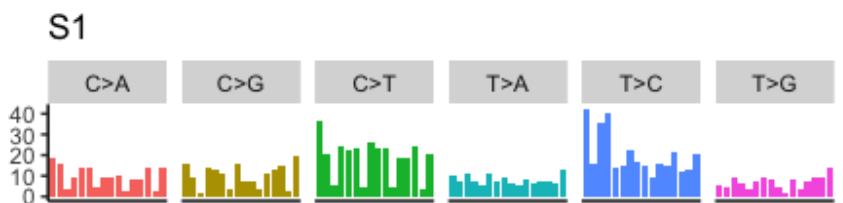

S3

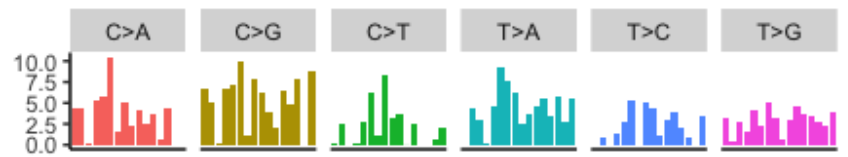

S5

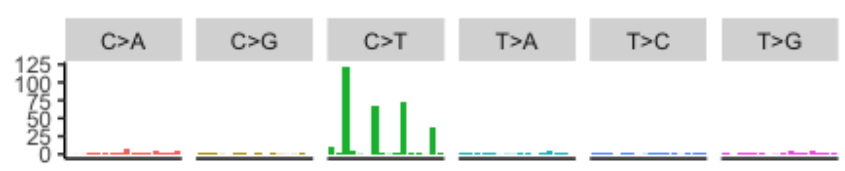

C signeR

S1

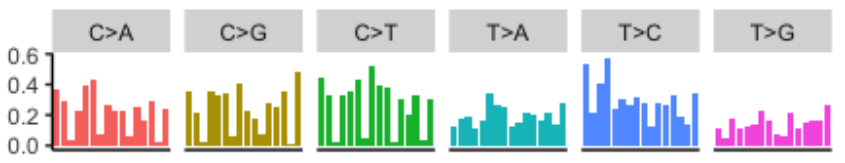
S3

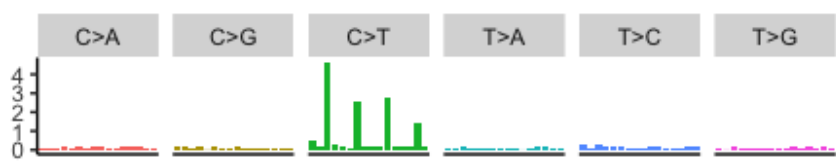

S5

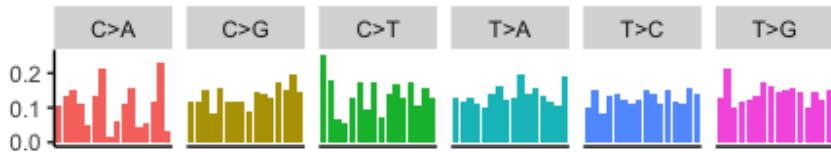

\section{S2}

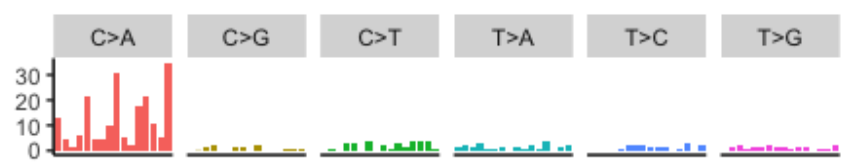

S4

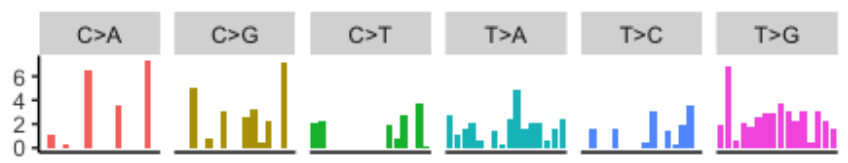
S6

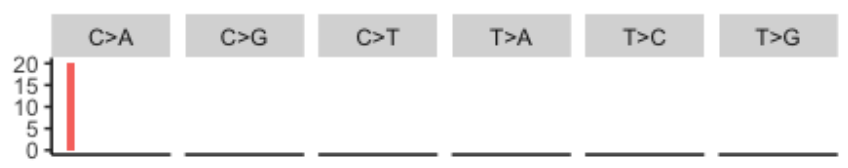

$\mathrm{S} 2$

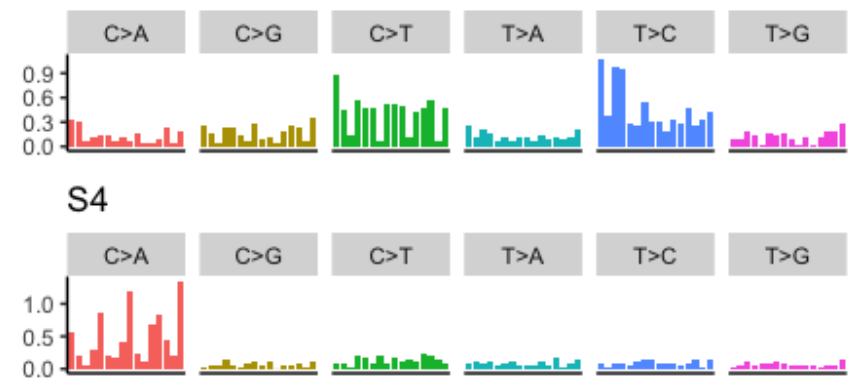

